\title{
Propagation and origin of warm anomalies in the Angola Benguela upwelling system in 2001
}

\author{
M. Rouault ${ }^{a, *}$, S. Illig ${ }^{\text {b, e }}$, C Bartholomae ${ }^{c}$, C.J.C. Reason ${ }^{a}$ and A. Bentamy ${ }^{d}$ \\ a Oceanography Department, University of Cape Town, Private Bag, Rondebosch 7701, South Africa \\ ${ }^{b}$ Jet Propulsion Laboratory, NASA, Pasadena, USA \\ ${ }^{c}$ National Marine Information and Research Centre, PO Box 912, Swakopmund, Namibia \\ 'Institut Français pour la Recherche et l'Exploitation de la Mer, Plouzané, France \\ e Legos, Toulouse, France \\ *: Corresponding author : Rouault M., email address : Mathieu.Rouault@uct.ac.za
}

\begin{abstract}
:
Warmer than average sea surface temperatures were observed by the Tropical Rainfall Mission Microwave Imager in the Angola Benguela Current system in late austral summer 2001 and persisted for about three months. These coastal anomalies extended offshore by 1 to $4^{\circ}$ longitude and were not due to local ocean atmosphere interaction or relaxation of the upwelling favorable southerly winds. Instead, they were remotely forced by ocean atmosphere interaction in the Tropical Atlantic. Satellite remote sensing and a linear ocean model suggest that relaxation of trade winds along the equator triggered Kelvin waves that crossed the basin within a month in early 2001 . Westerly wind anomalies were also observed in December 2000 and January 2001 over most of the Tropical Atlantic contributing to a warm preconditioning due to an enhancement of the oceanic annual cycle. This led to abnormal sea level heights near equatorial Africa that propagated southwards along the coast towards the Angola Benguela Frontal zone. This process increased the seasonal penetration of warm and salty water of tropical origin into the Angola Benguela upwelling system.
\end{abstract}

Keywords: Angola Benguela upwelling system; Tropical Atlantic variability; Ocean atmosphere interaction 


\section{Introduction}

Warmer than average upper ocean temperature events along the Angolan and Namibian Atlantic coastline $\left(5^{\circ} \mathrm{S}\right.$ to $\left.27^{\circ} \mathrm{S}\right)$ have a strong impact on the marine ecosystem and the rainfall of the region. The stronger events are called Benguela Niño (Shannon et al., 1986) by analogy to the southward propagation of warm water along the Equatorian and Peruvian coastline during $\mathrm{El}$ Niño. Benguela Niños have a strong impact on the coastal upwelling as low-nutrient, low oxygen, warm Angolan water is advected in the upwelling system in place of cold, nutrient rich upwelled water ([Shannon et al., 1986], [Monteiro et al., 2006] and [Bartholomae and van der Plas, in press]). Benguela Niños often lead to floods in Angola and Namibia and abundant rainfall in the usually arid Namib Desert ([Shannon et al., 1986] and [Rouault et al., 2003]). When warm events occur in late austral summer, during the maximum of annual sea surface temperature (SST) and rainfall, they further increase atmospheric instability and coastal rainfall (Hirst and Hastenrath, 1983), southern African rainfall (Nicholson and Entekhabi, 1987) and the negative impact on fisheries ([Boyer et al., 2001] and [Binet et al., 2001]).

Fig. 1 shows a schematic of the major oceanographic features off Angola and Namibia in late austral summer based on cruise data ([Gordon and Bosley, 1991], [Shannon and Nelson, 1996], [Gammelsrød et al., 1998], [Stramma and Schott, 1999], [Lass et al., 2000], [Mercier et al., 2003] and [Schott et al., 2004]). This includes the southward flowing warm Angola Current, the Angola Benguela Front at about $17.5^{\circ} \mathrm{S}$, the northwestward flowing cold Benguela current and the upwelling areas of the Benguela Current system. The region is fed by tropical water brought about by the Equatorial Undercurrent, the Gabon Current, the South Equatorial Counter Current and the South Equatorial Undercurrent. Other features likely to play an important role are the Angola Dome ([Voituriez, 1981] and [Yamagata and lizuka, 1995]) and the Congo River. Due to the paucity of dedicated oceanographic cruises, lack of observations in the region, a quasipermanent cloud cover and a strong annual cycle, this schematic is by no means an exact representation of the main oceanographic features.

Fig. 1 also shows the 1998-2005 mean March SST estimated with the Tropical Rainfall Measuring Mission Microwave Imager (TMI SST) together with the 1999-2005 mean March wind speed and direction inferred from the scatterometer SeaWinds onboard the QuikSCAT satellite. The position of the Angola Benguela Front (ABF) is found at about $17.5^{\circ} \mathrm{S}$ in March, its southernmost annual position (Hardman-Mountford, 2004; Veitch et al., 2006). The region is subject to the seasonal displacement of the South Atlantic Anticyclone that influences the changes in the location of the ABF (Meeuwis and Lutjeharms, 1990). Along the coast, the mean wind is mostly southerly, i.e., along-shore, and stronger south of the Angola Benguela Frontal zone where it drives pronounced upwelling. Wind favorable upwelling is mostly found south of 15 $S$ all the way to the tip of southern Africa ([Shannon and Nelson, 1996] and [Hardman-Mountford et al., 2003]).

Along the equator, the seasonal relaxation of easterly wind in austral summer, especially in the west of the Tropical Atlantic reduces the zonal pressure gradient, decreases the slope of the thermocline and contributes to the late austral summer seasonal warming of the upper ocean in the north of the domain shown in Fig. 1 ([Philander and Pacanowski, 1986] and [Carton and Zhou, 1997]).

During Benguela Niños, intrusions of warm water can reach as far as $25^{\circ} \mathrm{S}$ (Shannon and Nelson, 1996) about $8^{\circ}$ south of the ABF. The 1984 and 1995 Benguela Niños happened in late austral summer and were remotely forced by reduced trade winds in the western equatorial part of the Tropical Atlantic ([Philander, 1986], [Carton and Huang, 1994], [Vauclair and du Penhoat, 2001], [Florenchie et al., 2003], [Florenchie et al., 2004] and [Reason et al., 2006]). A sustained eastward propagation of warm anomalies in the Tropical Atlantic due to reduced tradewinds is usually called an Atlantic Niño. It is thought that during an Atlantic Niño, relaxation of trade winds in the western part of the Tropical Atlantic triggers Kelvin waves, propagating eastwards towards Africa. These propagations induce a deepening of the thermocline and a warming of the 
equatorial upwelling system in the eastern equatorial part of the Tropical Atlantic ([Hisard, 1980], [Philander, 1990], [Zebiak, 1993], [Carton et al., 1996] and [Illig et al., 2004]). The mechanisms linking Atlantic Niños and Benguela Niños are not well understood (Binet et al., 2001) but it seems that the warming in the Atlantic lag the warming of Angola by a season (Reason et al., 2006).

The aim of this paper is to describe the warm event of late austral summer 2001, the warmest event of its kind with the lowest oxygen rate (Bartholomae and van der Plas, in press) since the 1995 Benguela Niño, and to investigate the potential mechanisms leading to its origin and development. The paper is organized as follows: in Section 2, we present the various data sets and the equatorial model used. We then show in Section 3, the evolution of the warm event from February to May 2001 and the local ocean-atmosphere interactions. Having established that it was not produced by change in local wind intensity or air-sea exchange of energy, we use altimetric data and PIRATA mooring data in Section 4 to establish the equatorial origin of the event and tentatively explore the potential mechanisms that led to this particular warm event also using an ocean linear model that had some success in identifying Kelvin waves along the equator (Illig et al., 2004). Section 5 provides a discussion of the results presented in this paper, followed by conclusions.

\section{Data}

Regular monitoring lines off central and northern Namibia (Bartholomae and van der Plas, in press) provide 10-year time series (1996-2006) of in situ temperature and salinity measurements. In the present study, we use the $20^{\circ} \mathrm{S}$ and $23^{\circ} \mathrm{S}$ monitoring lines, constructed from $5 \mathrm{CTD}$ stations spaced at 2, 510,20 and 30 nautical miles from the coast. The temporal resolution at $20 \mathrm{~S}$ is approximately every three months and at $23 \mathrm{~S}$ it is monthly with a few exceptions such as January.

We use weekly TMI SST to describe the 2001 warm event. TMI measures the microwave energy emitted by the earth and its atmosphere over a wide swath width of $760 \mathrm{~km}$. An important feature of microwave retrievals is that SSTs can be measured through clouds beyond $35 \mathrm{~km}$ from the coast. This is a great advantage off Angola where data from combined infrared remote sensing and observation such as optimal interpolated Reynolds SST (Reynolds and Smith, 1994) are only available $40 \%$ of the time due to persistent cloud cover (Stammer et al., 2002). The interpolation scheme used in Reynolds SST tends to artificially extend the warm anomalies offshore. Moreover the lack of in situ observations in the region, cloud cover off Angola and resolution of Reynolds SST aggravate the problem. In spite of no TMI SST data within $35 \mathrm{~km}$ from the coast, SST in the Angola Benguela coastal upwelling zone is greatly improved using this data set (O'Neill et al., 2003, Fig. 1). Weekly TMI SST is available in near real time from December 1997 at a $1 / 4^{\circ}$ resolution. Prior to 1998, we used SST from the UKMO Hadley Centre (Rayner et al., 2003).

The wind anomalies were estimated with QuikSCAT data. We used 0.5 by $0.5^{\circ}$ gridded surface wind fields produced daily with the "kriging" technique over the global ocean (Bentamy et al., 2002). The present data set covers the period July 1999 to March 2005. The accuracy of the daily wind fields is determined by comparison with moored buoy wind speed and direction measurements in the Atlantic and Pacific oceans. For instance, the scatterometer wind accuracy results estimated through the comparisons with PIRATA buoys (Servain et al., 1998) in the Tropical Atlantic area indicate that these two surface wind data sets compare well. The overall wind speed bias, rms difference, correlation coefficient, and symmetrical regression are respectively $-0.52 \mathrm{~m} / \mathrm{s}, 1.66 \mathrm{~m} / \mathrm{s}, 0.84$, and 1.06 . For wind direction the mean difference is low, $<15^{\circ}$, and the corresponding standard deviation is about $27^{\circ}$.

We also used NCEP (Kalnay et al., 1996) reanalysed products to compare 2001 to conditions in the region since 1979. Because NCEP latent heat fluxes could be inaccurate in the data-sparse Tropical South East Atlantic region, we used satellite remote sensed latent heat fluxes (Bentamy et al., 2003). The latent heat flux estimations were tested against in situ data, including the 
Comprehensive Ocean-Atmosphere Data Set and moored buoys, and compared to surface flux estimates produced by numerical analyses of the National Center for Environmental Prediction and the European Center for Medium-Range Weather Forecasts (Bentamy et al., 2003). For instance, the flux comparisons between satellite and PIRATA data indicate that the mean of the residual between the two is quite low (less than $3 \mathrm{~W} / \mathrm{m}^{2}$ ), and the corresponding rms is less than $25 \mathrm{~W} / \mathrm{m}^{2}$. The correlation coefficient values estimated for each buoy are comparable and are close to 0.87 .

Precipitation rates were inferred from the Global Precipitation Climatology Project Version-2 monthly precipitation (GPCP-V2), a monthly analysis of surface precipitation at $2.5^{\circ}$ latitude $\times 2.5^{\circ}$ longitude resolution available from January 1979 to the present (Adler et al., 2003). GPCP-V2 includes precipitation estimates from satellite microwave and infrared data and surface rain gauge observations.

The weekly Sea level anomaly (SLA) data were supplied by AVISO/CLS (ftp.cls.fr). These data result from a global sub-optimal space time objective analysis of combined altimetric data from TOPEX/POSEIDON, Jason and ERS1/2 missions (Ducet et al., 2000) on a Mercator $1 / 3^{\circ}$ grid.

In order to investigate long equatorial wave propagations in early 2001, we used the Equatorial Atlantic Ocean Linear Model (OLM) developed by Illig et al. (2004). It is similar to the Cane and Patton (1984) model but with a higher resolution and more realistic coastlines. The model domain extends from $50^{\circ} \mathrm{W}$ to $10^{\circ} \mathrm{E}$ and from $28.875^{\circ} \mathrm{S}$ to $28.875^{\circ} \mathrm{N}$, with a horizontal resolution of $2^{\circ}$ in longitude and $0.25^{\circ}$ in latitude. The model time-step is 2 days. It includes 6 baroclinic modes with phase speed, projection coefficient and friction derived from a high-resolution OGCM simulation forced with realistic fluxes (Barnier et al., 2000). The results of the linear model forced with realistic winds were compared to various observations and to the OGCM in Illig et al. (2004). In the present study, the model is forced by the QuikSCAT wind stress anomalies estimated every 2 days with respect to the 2000-2005 climatology, following a spin-up with the year 2000 repeated five times. We will focus on the Sea Level Anomaly (SLA) signal along the equator and in particular on the gravest baroclinic mode (1 and 2) long equatorial Kelvin wave components. The reader is referred to Illig et al. (2004) for more details on the long equatorial wave decomposition in the Tropical Atlantic.

The 1998-2006 PIRATA Z20 anomaly data (Servain et al., 1998) indicate the depth of the $20 \mathrm{C}$ isotherm indicating roughly the mean position of the thermocline. It was produced by the data delivery and display web interface at http://www.pmel.noaa.gov/tao/disdel/

\section{Propagation of warm anomalies in the Angola Benguela upwelling system}

Fig. 2a shows the southward propagation of warm SST anomalies along the Angola and Namibian coastlines. We calculated the weekly anomalies from weekly TMI SST minus a 19982006 monthly average centered on the week of interest. Anomalies are plotted only every 2 weeks from February 2001 to May 2001. Positive SST anomalies first appeared at the end of January at the Angolan coast between $5^{\circ} \mathrm{S}$ and $17^{\circ} \mathrm{S}$ raising Angolan water temperature from about $28^{\circ} \mathrm{C}$ to $30^{\circ} \mathrm{C}$ as far south as $15^{\circ} \mathrm{S}$. It seems that this anomalous warm water started accumulating and intensifying in February at the Angola Benguela Frontal zone before propagating southwards in March in the coastal upwelling system of the Benguela Current to reach $26^{\circ} \mathrm{S}$ at the end of March 2001 . The anomaly remained positive in April from $13^{\circ} \mathrm{S}$ to $26^{\circ} \mathrm{S}$. Analysis of the SST charts shows that those anomalies extended offshore by 2 to $4^{\circ}$ longitude at the Angola Benguela Frontal zone and by about $1^{\circ}$ longitude at the southern limit of the event. In total the warm anomaly was sustained for about 3 months, and slightly modulated by the local wind conditions, which were on average upwelling favorable between $15^{\circ} \mathrm{S}$ and $25^{\circ} \mathrm{S}$. The 2001 persistent thermal anomaly can be likened to the 1984 and 1995 Benguela Niños and also the 1999 (Mohrholz et al., 2001) and 1996 warming (Florenchie et al., 2004). They occurred at the same time of the year ([Shannon et al., 1986] and [Gammelsrød et al., 1998]) but the surface expression of the 2001 event was not as strong (Rouault et al., 2003, Fig. 3) and it was shorter in duration than 1984 and 1995. 
Fig. 2b shows a time/latitude Hovmöller diagram of weekly SST anomalies off the African coast for 2001. SST anomalies were averaged from the coast to $3^{\circ}$ longitude offshore. The 2001 warm anomaly can be seen spreading polewards from February to the beginning of May 2001. This is the clearest indication of southward propagation of warm anomaly along the coast from the entire 1998-2006 TMI data set (Rouault et al., 2003 and Supplementary material).

Variability in the wind usually determines SST variability south of the ABF which is situated at about $17^{\circ} \mathrm{S}$ in late austral summer ([Shannon and Nelson, 1996], [Kostianoy and Lutjeharms, 1999] and [Colberg Reason, 2006]). Warm events south of the ABF at 15 South in the upwelling area are usually related to a weakening of the southerly wind or a spell of northerly wind (Shannon and Nelson, 1996). In the absence of long time series of daily wind speed in the domain, we investigated the variability of Quikscat wind stress in and compared it with the mean of 1999-2006.

Fig. $3 a$ shows the climatology of the meridional wind stress averaged from the coast to $2^{\circ}$ longitude offshore inferred from Quikscat (1999-2005). Wind favorable upwelling is mostly found south of $15 \mathrm{~S}$. The Quikscat climatology corresponds well to the climatology of Shannon and Nelson (1996) and Hardman-Mountford et al. (2003) even with no data roughly within $50 \mathrm{~km}$ from the coast. There is a good match between the Quikscat wind stress climatology and the major upwelling cells at Cape Frio, and Luderitz (Demarc et al., 2004; Veitch et al., 2006). A relaxation of the wind is observed in January-February in our domain study from about $23 \mathrm{~S}$ to $15 \mathrm{~S}$ that is linked to the seasonal polewards migration of the South Atlantic anticyclone and associated trade winds.

Fig. 3b presents a time-latitude Hovmöller diagram of Quikscat meridional wind stress anomalies from a 1999-2006 monthly mean centered on each week of interest off Angola and Namibia for the year 2001. Wind stress anomalies are averaged from the coast to $2^{\circ}$ longitude offshore and indicate that the wind stress was mostly normal from January to April 2001 with the first substantial relaxation of upwelling favorable wind in late April/May 2001. Although the wind stress anomaly was negative in February, it was not strong and long enough to be able to perturb the system for the 3 month period of the event. Fig. 3 shows that south of the ABF, only more intense and longer decreases in wind stress in October-November 2001 and in August 2001 can be linked with SST increases at the same period. Increase and decrease of wind speed seems to slightly modulate the event. The first important wind stress anomaly happened at the end of April 2001 and probably contributed to extend the 2001 warm event. Fig. 4 shows a time series for each year since 2000 of TMI SST and Quickscat wind speed anomalies averaged from 19 S to 25 $S$ in the upwelling system South of the ABF confirm that the warming in 2001 was sustained and did not respond much to the relatively weak increase or decrease of early 2001 . Additional material shows Hovmöller of SST and wind stress anomalies from 2000 to 2005 and confirms the lesser role of local wind speed there.

Fig. 5a,b,c,d illustrates the temperature and salinity anomalies observed during the end of March 2001 at the $20^{\circ} \mathrm{S}$ monitoring line and end of April at the $23^{\circ} \mathrm{S}$ monitoring line along a 30 nautical miles transect off Namibia respectively. The largest anomalies, both for salinity and temperature were observed at the northern line $\left(20^{\circ} \mathrm{S}\right)$. Here salinities were up to $0.5 \mathrm{psu}$ higher than the tenyear average, extended to $120 \mathrm{~m}$ depth and covered almost the entire water column throughout the transect which quite important for the region. The intensity of the positive salinity anomaly at $20^{\circ} \mathrm{S}$ is a clear indication of the presence of warm saline Angolan water that advected southward during the 2001 warm event. This feature was also evident further south at $23^{\circ} \mathrm{S}$ but anomalies were significantly weaker. Temperature differences as high as $3-4{ }^{\circ} \mathrm{C}$ confined to the upper 40 $60 \mathrm{~m}$ were measured at $20^{\circ} \mathrm{S}$ with the slope deepening towards the coast. Further south at $23^{\circ} \mathrm{S}$, the anomaly was limited to the upper $20-40 \mathrm{~m}$ and confined to the coast but Fig. 4 shows that there was upwelling favorable wind from March to mid April. Most important, in 2001 oceanographic sections were showing a very low oxygen concentration, the lowest since 1995 (Fig. 6, Bartholomae and van der Plas, in press). 


\section{Ocean atmosphere interaction}

Because variations in air-sea exchange of energy can lead to substantial anomalies in SST, we studied monthly mean and anomaly of Hadley SST and GPCP-V2 (Adler et al., 2003) rainfall, NCEP-2 latent, sensible and radiative heat fluxes, surface wind speed averaged in the region $20^{\circ} \mathrm{S}-10^{\circ} \mathrm{S}, 8^{\circ} \mathrm{E}$-coast from 1979 to 2003 . We also analyzed the averaged February, March and April latent heat flux in the region defined above and found it to be quite substantial (mean $90 \mathrm{~W} / \mathrm{m}^{2}$, standard deviation: $13 \mathrm{~W} / \mathrm{m}^{2}$ ) and it dominates the turbulent heat fluxes. NCEP-2 averaged surface winds are moderate, steady and mostly southerly. The mean southerly component is $4.85 \mathrm{~m} / \mathrm{s}$ (standard deviation: $0.25 \mathrm{~m} / \mathrm{s}$ ) and the mean easterly component is $0.75 \mathrm{~m} / \mathrm{s}$ (standard deviation: $0.08 \mathrm{~m} / \mathrm{s}$ ). The mean SST is $25.6{ }^{\circ} \mathrm{C}$ with a standard deviation of $0.9^{\circ} \mathrm{C}$. Note that the standard deviation of SST is substantially higher than wind speed in this region.

Fig. 6 shows the normalized late summer (FMA) anomaly (anomaly divided by seasonal standard deviation) for late summer of total rainfall, SST, latent heat flux, meridional wind (southerly is positive) and zonal wind (westerly is positive) wind for the 1979-2003 period. Significant oceanic warm events are those of about one standard deviation or more, and hence, 1984, 1995, 1999 and 2001 stand out. There is also a warming trend seen in SST for the period that seems to be due to several warm events in the area since 1995 ([Rouault et al., 2003], [Florenchie et al., 2004] and [Veitch et al., 2006]). This warming trend is confirmed by Casey and Cornillon (2001) and Jones and Moberg (2003) and Hardman-Mountford (2003). This trend masks the significance of the surface expression of the 1984 Benguela Nino and increases the importance of the 1999 and 2001 warming. The FMA SST normalized anomaly from the 1979-2003 seasonal mean was 0.9 for 1984, 2.2 for 1995, 1 for 1999 and 1.3 for 2001. The highest latent heat flux anomalies are in 1995 and 2001 meaning that the ocean was losing more heat than usual during those years. The higher southerly wind component in 2001 confirms the results presented in Fig. 3 and Fig. 4. More southerly wind implies stronger than normal upwelling and hence cools the upper ocean. The reason for the large anomalous fluxes in 1995 and 2001 could be that the difference between the specific humidity of the air and the sea surface increases quickly when the SST increases leading to more evaporation (latent heat flux). The South Atlantic anticyclone advects colder and drier air from the south at this time of the year (Fig. 1 and Fig. 3). The unexpected result is that the latent heat flux contributes to cool the warm events in 1995 and 2001. This result also confirms Hirst and Hastenrath (1983) hypothesis that there is more evaporation at the coast during warm events off Angola.

In order to show that the warming was not due to a preconditioning of the area off Angola before the warm event, we studied the same parameters in the months preceding the warm event (not shown). The results indicate little preconditioning of the 2001 warm event by ocean-atmosphere interaction or upwelling relaxation in December 2000 and January 2001 that could have warmed the water prior to the event.

Fig. 6 shows that the latent heat fluxes play a rather passive role by cooling the warm events at the surface, thereby contributing to their demise. Moreover since the rain, and hence cloud cover, was greater than average in 1995 and 2001, the short wave radiation (not shown) was below average adding a further cooling effect at the surface during warm events. In conclusion, we have argued that relaxation of the typical upwelling and local air-sea interactions are not the major contributors to the origin of the warming in 2001.

\section{Origin of the warm anomalies}

To find the origin of the event, we analyzed merged sea surface height (SSH) altimetric data and Quikscat wind data for the entire Tropical Atlantic and we used a linear model to investigate wave dynamic along the equator. SSH) are usually calculated against a mean annual reference in the 
Tropical Atlantic, the seasonal variability is much stronger than the interannual variability (Philander, 1990). It is therefore important to remove the seasonal signal to detect abnormal events in the Tropical Atlantic in SSH, especially if they are merely an enhancement of the seasonal cycle.

Fig. $7 a$ and $b$ show time/longitude Hovmöller diagrams along the equator and along the African coast of SSH anomalies estimated first with respect to the annual mean (Fig. 7a,b) and then with respect to the seasonal cycle (Fig. 7c,d). Fig. 7c shows evidence of rapid propagation of higher than normal positive SSH from January 2001 to March 2001 across the equatorial Atlantic, which is associated with an intensification of the observed SSH seasonal cycle (Fig. 7a). Note that Fig. 7c also suggests that a preconditioning took place in January 2001 in the eastern equatorial part of the tropical Atlantic; where above normal positive SSH is observed in early 2001 . At the African coast, the altimetric data clearly show that this equatorial propagation of positive $\mathrm{SSH}$ is coherent with a relatively slower southward propagation of $\mathrm{SSH}$ along the African coasts (Fig. $7 \mathrm{~d}$ ). The above normal SSH reach $20^{\circ} \mathrm{S}$ in March 2001, which is consistent with the SST propagation observed along the African coasts (cf. Fig. 2 and Section 3). We propose that the warm anomalies observed in the Angola Benguela upwelling system in late austral summer 2001 originate from this equatorial propagation, which in turn propagates southward so that the upwelling favorable winds off southern Angola/northern Namibia bring warm sub-surface water to the surface. This is confirmed by Fig. 8 who is a seasonal anomaly of SSH for February (top), March (middle), and April showing that an exaggeration of the seasonal cycle took place in 2001 that lasted for about 3 months. In Supplementary material we show the mean SSH for those months and the anomalies from the mean in 1995 at the same period of those years showing similitude with 2001.

In order to investigate the eastward equatorial propagation evidenced by the altimetric data, we used the OLM (cf. Section 2) forced by QuikSCAT wind stress anomalies. This model provides evidence of the significant role of the long equatorial wave propagations (Kelvin and Rossby) in the tropical Atlantic interannual variability whose signatures, by comparison to the tropical Pacific, are more difficult to determine in the observed altimeter data because of the reduced size of the basin and the contribution of several baroclinic modes (Illig et al., 2004). Nevertheless, this model is an efficient tool to interpret the altimetric signal along the equator and enabled Illig et al. (2006) to investigate the long equatorial wave contribution to the observed equatorial Atlantic 1996 warm event.

QuikSCAT zonal wind stress anomalies along the equator are displayed in Fig. 9a, along with the OLM first and second baroclinic mode Kelvin wave contributions to SSHA along the equator (Fig. $7 \mathrm{~b}, \mathrm{c})$. The OLM results allow us to identify a first baroclinic mode Kelvin wave that crosses the basin in January-February 2001, which is in agreement with the altimetric signal presented in Fig. 7c. According to the OLM dynamics, this Kelvin wave is forced in early 2001 by the anomalous zonal wind stress in the western equatorial part of the Tropical Atlantic shown in Fig. 9a, associated with a local trade wind relaxation. It propagates eastward with a phase speed value of $2.3 \mathrm{~m} / \mathrm{s}$, the same order of magnitude as those measured by Katz (1997) or estimated by Delecluse et al. (1994). The analysis of the OLM second baroclinic mode Kelvin contribution to SSHA highlights a propagation from February 2001 to April 2001. It was triggered by anomalous zonal wind stress along the equatorial band, and intensified by intense anomalous zonal wind stress in eastern basin in early March 2001. This slower propagation can also be determined in the altimetric signal, and takes slightly less than 2 months to cross the basin, in agreement with the theoretical phase speed of a second baroclinic Kelvin wave $(1.34 \mathrm{~m} / \mathrm{s})$. The summed contribution of the first two baroclinic Kelvin wave to SSHA (not shown) closely resembles the altimetric signal, and explains the spreading in time of the propagation seen in Fig. 7c. Moreover, the signature of the eastward propagations can also be observed in the equatorial Atlantic subsurface, as shown by the Z20 anomaly estimated with the 1998-2006 PIRATA data (Fig. 9d).

The eastward propagating Kelvin waves reach the African boundary from February 2001 to April 2001 in agreement with the altimetric signal. Examination of charts of weekly SSH anomalies from the seasonal cycle (not shown) show that higher than normal SSH appeared east of the 
Greenwich meridian during the second week of January 2001. According to the OLM results (Fig. 9), these anomalies are associated with a second baroclinic mode Kelvin wave, triggered by anomalous zonal wind stress in the center of the basin in December 2000 and January 2001. Due to local anomalous zonal wind stress, this anomaly intensified slightly during January before spreading southward. The SSH anomalies along the coast intensified and propagated gradually southwards in February and March 2001 linking the 2001 warm event to the equatorial region and suggesting an intensification of the mean annual cycle by the event.

The trade wind relaxation and westerly wind along the equator from late December 2000 to February 2001 seems to have played an important role in the onset of the 2001 warm event, as was the case for the 1984 and 1995 Benguela Niños ([Carton and Huang, 1994], [Florenchie et al., 2003] and [Florenchie et al., 2004]). However, it is not clear if the 2001 warming was due to the abovementioned Kelvin wave triggered by the relaxation of the trade winds in January between $35 \mathrm{~W}$ and $25 \mathrm{~W}$ near the Equator, by the abnormally strong westerly wind in the east in December 2000 and January 2001 or by the resulting higher than normal integrated westerly wind component for December and January over all the equatorial region. However, it could be that the timing of an equatorial Kelvin waves relative to the annual cycle is the key for the penetration of warm anomaly south of the Angola Benguela Frontal Zone.

\section{Discussion}

The results presented here demonstrate that the 2001 warm event was remotely forced. It seems than higher than normal SSH have propagated to the Front at $17 \mathrm{~S}$. We now discuss a possible scenario where higher than normal SSH were the results of wave dynamics and exaggeration of the seasonal cycle all the way to the ABF. This would have deepened the thermocline, then warmed up the upper ocean and created stronger than normal poleward geostrophic current that would have strengthen the Angola Current. Advection could have then propagated the anomaly from the front to about $25 \mathrm{~S}$. However, wind fluctuations could have modulated the events especially at the end of April 2001.

The intrusion of warm water in the northern Benguela current along the coast and the associated displacement of the ABF is indeed a seasonal feature (Boyd et al., 1987). Although little is known about the Angola Current, several cruises in the Angola Benguela current system ([Moroshkin et al., 1970], [Bubnov, 1972], [Bubnov and Egorikhin, 1980], [Lass et al., 2000] and [Mohrholz et al., 2001]) measured current speed of 0.5 to $0.7 \mathrm{~m} / \mathrm{s}$ in the Angola current. They found that the Angola Current is weaker in winter and stronger in summer, weaker off the north of Angola and stronger to the south. It has a depth of about $200 \mathrm{~m}$ and a width of about 200 to $300 \mathrm{~km}$. A comprehensive survey done in April 1997 at the ABF and in the Angola Current by Lass et al. (2000) showed that most of the water feeding the Angola Current at the time was coming from the northwest and was composed of Tropical Atlantic upper ocean water. Their results suggest that the South Equatorial Atlantic Counter Current along the northern limb of the Angola Gyre fed the Angolan Current. The model study of Carton and Huang (1994) and the analysis of Philander (1986) have also noted an increased South Equatorial Atlantic Counter Current during the onset of the 1984 Benguela Niño. Mercier et al. (2003) sampled along two lines in January 1995 along $9 \mathrm{~W}$ and in April 1995 along 5 S. They measured an eastward moving South Equatorial Counter Current and South Equatorial Undercurrent contributing to the northern limb of the Angola Gyre. They concluded that the circulation through the Angola Gyre was responsible for half the transport calculated for the Angola Current.

A southward pulse of warm Angolan water was sampled at the Angola Benguela front during a cruise in April 1999 (Mohrholz et al., 2001; John et al., 2004) with similar results. Note that Illig et al., 2004 suggested Kelvin waves in February March 1999 with timing consistent with the April 1999 warming. According to TMI SST the 1999 warming was not as intense as 2001, only lasted a month and propagated to 20 S only (Rouault and Lutjeharms, 2003). Hovmöller for 1999 along 
the Atlantic shown in Supplementary material suggests also Kelvin wave propagation at the origin of the event.

Since the winds in the Benguela Current region south of the ABF were not weaker than average during, or prior, to the development of the 2001 warm event, we assume that the Benguela Current northwestward surface transport and the upwelling system itself were not weaker than usual. The influence of the Benguela current on the poleward propagation of warm water is probably more important when the southerly wind is stronger and it may explain why some of the Kelvin waves identified by Illig et al. (2004) and in Fig. 7 are not followed by a warming in the upwelling system of the northern Benguela Current. The 2001 warming as well as the 1984 and 1995 Benguela Niños and the 1999 warm event occurred at the same time of the year and this suggests a phase locking of Benguela Niños to the late summer when the ABF is further south. Fig. 1 shows that the coastline starts to veer in a southeastwards direction at about $17 \mathrm{~S}$, near the southernmost position of the Angola Benguela front that happens to occur in March. The seasonal southerly winds are weakest in the northern upwelling system when the South Atlantic Anticyclone is furthest south in early summer. All these factors imply that the 2001 warm event and perhaps the 1984 and 1995 Benguela Niños and the 1999 warm events may be related to an intensification of the annual cycle that then leads to a stronger than normal penetration of the Angola Current in the northern upwelling system.

A phase locking of Benguela Niños to late austral summer could explain why Kelvin waves in the Tropical Atlantic are not necessarily followed by Benguela Niños. For instance, the TRMM SST data set shows several warm events off Angola that did not penetrate in the upwelling system (Rouault and Lutjeharms, 2003). Florenchie et al. (2004) have noted several warm events of minor intensity that happened in other seasons and were linked to wind shifts in the Tropical Atlantic. They did not penetrate as far south as for the 1984, 1995, 1999 and 2001 warm event. There are some limitations to our study, especially regarding the mechanisms, that should be mentioned. First, we could not look for potential propagation of coastal Kelvin waves, a mechanism suggested by Moore et al. (1978) but never demonstrated off Angola/Namibia due to lack of a proper observing system. Altimetry also has limitations in the Tropical Atlantic due to the narrowness of the basin and both altimetry and TMI SST are only valid roughly $35 \mathrm{~km}$ offshore.

\section{Conclusion}

Warm SST anomalies propagated in the northern Benguela region from February to April 2001 in a similar fashion to the 1984 and 1995 Benguela Niños, although it was not as intense and the warming was shorter. Substantial SST anomalies started to appear at about 5 to $10 \mathrm{~S}$ and propagated along the coast to about $25 \mathrm{~S}$. Ocean-atmosphere interaction acted to cool the event that was slightly modulated by the local wind stress. The origin of the warm event can be traced to anomalous behaviour in the Tropical Atlantic along the equator. This could have increased the accumulation of warm water along the Angolan coast and or deepened the thermocline through the action of wave dynamic leading to an intensification of the Angola current with a timing that favored the intrusion of warm water in the northern upwelling system south of the Angola Benguela Front at $17 \mathrm{~S}$. There is also a strong indication that Kelvin waves acted to propagate the anomalies along the Equator. In any case, the equatorial origin of the event has been demonstrated in this study as it was for the 1984 and 1995 Benguela Niños. However, stronger than average westerly winds east of the Greenwich meridian could also have contributed to the event by enhancing the seasonal appearance of high SSH near Africa in austral summer 2001. The lack of in situ data motivates the extension of the PIRATA array in the South East Tropical Atlantic (Servain et al., 1998), which will be well suited to monitor Benguela Niños upstream of the event and link the Angola Benguela Current system to the Tropical Atlantic. Tide gauges are also needed along the coast together with a fine resolution ocean model for the South East Atlantic in order to help determine the relative roles of Angola Current advection of the signal and coastally trapped waves. Such a system will also help assess the potential contribution of the Congo River outflow which is not well understood. 


\section{Acknowledgements}

Mathieu Rouault wishes to thank the WRC for financial support. TMI data are produced by Remote Sensing Systems, http://www.ssmi.com/, and sponsored by NASA's Earth Science Information Partnerships (ESIP): a federation of information sites for Earth Science; and by NASA's TRMM Science Team. We thank CERSAT for producing and making available QuikSCAT wind data and the CDC for the Reynolds SST. MR thanks the WRC and CNRS/NRF cooperative program for financial support. Special thanks to Geoff Bailey who warned us about the warm event off Angola in 2001, Boris Dewitte and Pierric Penven for advice and Herve LeTraon from CLS for making the T/P ERS merged product available. This is a contribution to the BCLME program. We acknowledge the TAO Project Office for the PIRATA data and their data and display web based interface.

\section{References}

Adler et al., 2003 R.F. Adler, G.J. Huffman, A. Chang, R. Ferraro, P. Xie, J. Janowiak, B. Rudolf, U. Schneider, S. Curtis, D. Bolvin, A. Gruber, J. Susskind, P. Arkin and E. Nelkin, The Version-2 Global Precipitation Climatology Project (GPCP) monthly precipitation analysis (1979-Present), J. Hydrometeorol. 4 (2003), pp. 147-1167.

Barnier et al., 2000 Barnier, B., the CLIPPER project team, 2000. 1/6 reference experiment, 1/6 Atlantic circulation model forced by the ECMWF climatology: preliminary results. LEGI report number CLIPPER-R2-2000.

Bartholomae and van der Plas, in press Bartholomae C.H., van der Plas, A., in press. Towards the development of environmental indices of the Namibian shelf, with particular reference to fisheries management. Afr. J. Mar. Sci.

Bentamy et al., 2002 A. Bentamy, K.B. Katsaros, W.M. Drennan and E.B. Forde, Daily surface wind fields produced by merged satellite data, Gas Transfer at Water Surfaces, Geophys. Monogr., Amer. Geophys. Union vol. 127 (2002), pp. 343-349.

Bentamy et al., 2003 Bentamy, Abderrahim, Katsaros, B. Kristina, Mestas-Nuñez, M. Alberto, Drennan, M. William, B. Evan Forde and H. Roquet, Satellite estimates of wind speed and latent heat flux over the global oceans, J. Climate 16 (4) (2003), pp. 637-656.

Binet et al., 2001 D. Binet, B. Gobert and L. Maloueki, El Niño-like warm events in the Eastern Atlantic $\left(6^{\circ} \mathrm{N}, 20^{\circ} \mathrm{S}\right)$ and fish availability from Congo to Angola (1964-1999), Aquat. Living Resour. 14 (2001), pp. 99-113.

Boyd et al., 1987 A.J. Boyd, J. Salat and M. Maso, The seasonal intrusion of relatively saline water on the shelf off northern and central Namibia: the Benguela and comparable ecosystems, South Afr. J. Mar. Sci. 5 (1987), pp. 107-120. 
Boyer et al., $2001 \mathrm{H}$. Boyer, J. Boyer, I. Fossen and A. Kreiner, Changes in abundance of the northern Benguela sardine stock during the decade 1990-2000, with comments on the relative importance of fishing and the environment, South Afr. J. Mar. Sci. 23 (2001), pp. 76-84.

Bubnov, 1972 V.A. Bubnov, Structure and characteristics of the oxygen minimum layer in the Southeastern Atlantic, Oceanology 12 (1972), pp. 193-201.

Bubnov and Egorikhin, 1980 V.A. Bubnov and V.D. Egorikhin, Study of water circulation in the Tropical Atlantic, Deep-Sea Res., A, Oceanogr. Res. Pap. 26 (1980), pp. 125-136 (Suppl.).

Cane and Patton, 1984 M.A. Cane and R.J. Patton, A numerical model for low frequency equatorial dynamics, J. Phys. Oceanogr. 14 (1984), pp. 1853-1863.

Carton and Huang, 1994 J.A. Carton and B. Huang, Warm events in the Tropical Atlantic, J. Phys. Oceanogr. 24 (1994), pp. 888-903.

Carton and Zhou, 1997 J.A. Carton and Z.X. Zhou, Annual cycle of sea surface temperature in the Tropical Atlantic ocean, J. Geophys. Res. 102 (1997), pp. 27813-27824.

Carton et al., 1996 J.A Carton, X. Cao, B.S. Giese and A.M. da Silva, Decadal and interannual SST variability in the Tropical Atlantic, J. Phys. Oceanogr. 26 (1996), pp. 1165-1175.

Casey and Cornillon, 2001 K.S. Casey and P. Cornillon, Global and regional SST trends, J. Climate 14 (2001), pp. 3801-3818.

F. Colberg and C.J.C. Reason, Modelling the Angola Benguela Frontal Zone: sensitivity to atmospheric forcing, Geophy. Res. Lett 33 (19) (2006), p. L19608.

Delecluse et al., 1994 P. Delecluse, J. Servain, C. Levy, K. Arpe and L. Bengtsson, On the connection between the 1984 Atlantic warm event and the 1982-1983 ENSO, Tellus 46 (1994), pp. 448-464.

Ducet et al., 2000 N. Ducet, P.-Y. Le Traon and G. Reverdin, Global high resolution mapping of ocean circulation from TOPEX/Poseidon and ERS-1/2, J. Geophys. Res. 105 (2000), pp. 1947719498.

Florenchie et al., 2003 P. Florenchie, J.R.E. Lutjeharms, C.J.C. Reason, S. Masson and M. Rouault, Source of the Benguela Niños in the South Atlantic Ocean, Geophys. Res. Lett. 30 (2003).

Florenchie et al., 2004 P. Florenchie, C.J.C. Reason, J.R.E. Lutjeharms, M. Rouault, C. Roy and S. Masson, Evolution of interannual warm and cold events in the South-East Atlantic Ocean, J. Climate 17 (2004), pp. 2318-2334.

Gammelsrød et al., 1998 T. Gammelsrød, C.H. Bartholomae, D.C. Boyer, V.L.L. Filipe and M.J. O'Toole, Intrusion of warm surface water along the Angolan-Namibian coast in February-March 1995: the 1995 Benguela Niño, South Afr. J. Mar. Sci. 19 (1998), pp. 41-56.

Gordon and Bosley, 1991 A.L. Gordon and K.T. Bosley, Cyclonic gyre in the Tropical South Atlantic, Deep-Sea Res. 38 (1991), pp. S323-S343 (Suppl.). 
Hardman-Mountford et al., 2003 N.J. Hardman-Mountford, A.J. Richardson, J.J. Agenbag, E. Hagen, L. Nykjaer, F.A. Shillington and C. Villacastin, Ocean climate of the southeast Atlantic observed from satellite data and wind models, Prog. Oceanogr. 59 (2003), pp. 181-221.

Hirst and Hastenrath, 1983 C. Hirst and S. Hastenrath, Atmosphere-ocean mechanisms of climate anomalies in the Angola-Tropical Atlantic sector, J. Phys. Oceanogr. 13 (1983), pp. $1146-1157$.

Hisard, 1980 P. Hisard, Observations de reponses de type "El Niño" dans l'Atlantique tropical oriental golfe de guin!ee, Oceanol. Acta 3 (1980), pp. 69-78.

Illig et al., 2006 S. Illig, D. Gushchina, B. Dewitte, N. Ayoub and Y. du Penhoat, The 1996 Equatorial Atlantic Warm Event: origin and mechanisms, Geophys. Res. Lett. 33 (2006), p. L09701.

Illig et al., 2004 S. Illig, B. Dewitte, N. Ayoub, Y. du Penhoat, G. Reverdin, P. De Mey, F. Bonjean and G.S.E. Lagerloef, Interannual long equatorial waves in the Tropical Atlantic from a high resolution OGCM experiment in 1981-2000, J. Geophys. Res. 109 (C2) (2004), p. C02022.

Jones and Moberg, 2003 P.D. Jones and A. Moberg, Hemispheric and large-scale surface air temperature variations: an extensive revision and an update to 2001, J. Climate 16 (2003), pp. 206-223.

Kalnay et al., 1996 E. Kalnay et al., The NCEP/NCAR, 40-year reanalysis project, Bull. Am. Meteorol. Soc. 77 (1996), pp. 437-471.

Katz, 1997 E.J. Katz, Waves along the equator in the Atlantic, J. Phys.Oceanogr. 27 (1997), pp. 2536-2544.

Kostianoy and Lutjeharms, 1999 A.G. Kostianoy and J.R.E. Lutjeharms, Atmospheric effects in the Angola-Benguela Frontal Zone, J. Geophys. Res. 104 (1999), pp. 20,963-20,970.

Lass et al., 2000 H.U. Lass, M. Schmidt, V. Mohrholz and G. Nausch, Hydrographic and current measurements in the area of the Angola-Benguela front, J. Phys. Oceanogr. 30 (2000), pp. 2589-2609.

Meeuwis and Lutjeharms, 1990 J.M. Meeuwis and J.R.E. Lutjeharms, Surface thermal characteristic of the Angola-Benguela front, South Afr. J. Mar. Sci. 9 (1990), pp. 261-279.

Mercier et al., $2003 \mathrm{H}$. Mercier, M. Arhan and J.R.E. Lutjeharms, Upper-layer circulation in the eastern Equatorial and South Atlantic Ocean in January-March 1995, Deep-Sea Res., Part 1, Oceanogr. Res. Pap. 50 (2003), pp. 863-887.

Mohrholz et al., 2001 V. Mohrholz, M. Schmidt and J.R.E. Lutjeharms, The hydrography and dynamics of the Angola-Benguela frontal zone and environment in April 1999, South Afr. J. Sci. 97 (2001), pp. 199-208.

Monteiro et al., 2006 P.M.S. Monteiro, A. van der Plas, V. Mohrholz, E. Mabille, A. Pascal and W. Joubert, Variability of natural hypoxia and methane in a coastal upwelling system: oceanic physics or shelf biology?, Geophys. Res. Lett. 33 (2006), p. L16614. 
Moore et al., 1978 D.W. Moore, P. Hisard, J. McCreary, J. Merle, J. O'Brien, J. Picaut, J.M Verstraete and C. Wunsch, Equatorial adjustment in the Eastern Atlantic, Geophys. Res. Lett. 5 (1978), pp. 637-640.

Moroshkin et al., 1970 K.V. Moroshkin, V.A. Bubnov and R.P. Bulatov, Water circulation in the eastern South Atlantic, Oceanology 10 (1970), pp. 27-34.

Nicholson and Entekhabi, 1987 S.E. Nicholson and D. Entekhabi, The nature of rainfall variability in equatorial and southern Africa: relationships with SST along the southwestern coast of Africa, J. Clim. Appl. Meteorol. 26 (1987), pp. 561-578.

O'Neill et al., 2003 L.W. O'Neill, D.B. Chelton and S.K. Esbensen, Observations of SST-induced perturbations of the wind stress field over the Southern Ocean on seasonal timescales, J. Climate 16 (2003), pp. 2340-2354.

Philander, 1986 S.G.H. Philander, Unusual condition in the Tropical Atlantic in 1984, Nature 322 (1986), pp. 236-238.

Philander, 1990 S.G.H. Philander, El Niño, La Nina and the Southern Oscillation, Academic Press (1990) 293 pp..

Philander and Pacanowski, 1986 S.G.H. Philander and R.C. Pacanowski, A model of the seasonal cycle of the Tropical Atlantic, J. Geophys. Res. 91 (1986), pp. 14 192-14 206.

Rayner et al., 2003 N.A. Rayner, D.E. Parker, E.B. Horton, C.K. Folland, L.V. Alexander, D.P. Rowell, E.C. Kent and A. Kaplan, Global analyses of sea surface temperature, sea ice, and night marine air temperature since the late nineteenth century, J. Geophys. Res. 108 (D14) (2003), p. 4407.

Reason et al., 2006 C.J.C. Reason, P. Florenchie, M. Rouault and J. Veitch, Influences of large scale climate modes on the BCLME region. In: V. Shannon and C. Moloney, Editors, Chapter 10 in Forecasting of the Benguela Ecosystem (2006).

Reynolds and Smith, 1994 R.W. Reynolds and T.M. Smith, Improved global sea surface temperature analyses using optimum interpolation, J. Climate 7 (1994), pp. 929-948.

Rouault and Lutjeharms, 2003 M. Rouault and J.R.E. Lutjeharms, Microwave satellite remote sensing of SST around Southern Africa, South Afr. J. Sci. 99 (2003), pp. 489-494.

Rouault et al., 2003 M. Rouault, P. Florenchie, N. Fauchereau and C.J.C. Reason, South east Tropical Atlantic warm events and southern African rainfall, Geophys. Res. Lett. 30 (5) (2003).

Schott et al., 2004 F. Schott, J.P. McCreary Jr. and G.C. Johnson, Shallow overturning circulations of the tropical-subtropical oceans. Earth's Climate: the Ocean Atmosphere Interaction. Geophys. Monogr., Vol. 147, Amer. Geophys. Union (2004), pp. 261-304.

Servain et al., 1998 J. Servain, M.J. Busalacchi, A.D. McPhaden, G. Moura, M. Reverdin, Vianna and S.E. Zebiak, A Pilot Research Moored Array in the Tropical Atlantic (PIRATA), Bull. Am. Meteorol. Soc. 79 (1998), pp. 2019-2031.

Shannon and Nelson, 1996 L.V. Shannon and G. Nelson, The Benguela: large scale features and processes and system variability. In: G. Wefer, W.H. Berger, G. Siedler and D.J. Webb, Editors, The South Atlantic: Present and Past Circulation, Springer, Berlin (1996), p. 644. 
Shannon et al., 1986 L.V. Shannon, A.J. Boyd, G.B. Brundrit and J. Taunton-Clark, On the existence of an El Niño-type phenomenon in the Benguela system, J. Mar. Res. 44 (1986), pp. 495-520.

Stammer et al., 2002 D. Stammer, F.J. Wentz and C.L. Gentemann, Validation of microwave SST measurements for climate purposes, J. Climate 16 (2002), pp. 73-87.

Stramma and Schott, 1999 L. Stramma and F. Schott, The mean flow field of the Tropical Atlantic ocean, Deep-Sea Res. 46 (1999), pp. 279-303.

Vauclair and du Penhoat, 2001 F. Vauclair and Y. du Penhoat, Interannual variability of the upper layer of the Tropical Atlantic Ocean from in situ data between 1979 and 1999, Clim. Dyn. 17 (2001), pp. 527-546.

Veitch et al., 2006 J. Veitch, P. Florenchie and F.A. Shillington, Seasonal and interannual fluctuations of the Angola Benguela Frontal Zone (ABFZ) using $4.5 \mathrm{~km}$ resolution satellite imagery from 1982 to 1999, Int. J. Remote Sens. (2006).

Voituriez, 1981 B. Voituriez, Les sous-courants equatoriaux nord et sud et la formation des domes thermiques tropicaux, Ocean. Acta 4 (1981), pp. 497-506.

Yamagata and lizuka, 1995 T. Yamagata and S. lizuka, Simulation of the tropical thermal domes in the Atlantic: a seasonal cycle, J. Phys. Oceanogr. 25 (1995), pp. 2,129-2,140.

Zebiak, 1993 S.E. Zebiak, Air-sea interaction in the equatorial Atlantic region, J. Climate 6 (1993), pp. 1567-1586.

\section{Appendix A. Supplementary data}

Supplementary data associated with this article can e found, in the online version, at doi:10.1016/j.jmarsys.2006.11.010. 


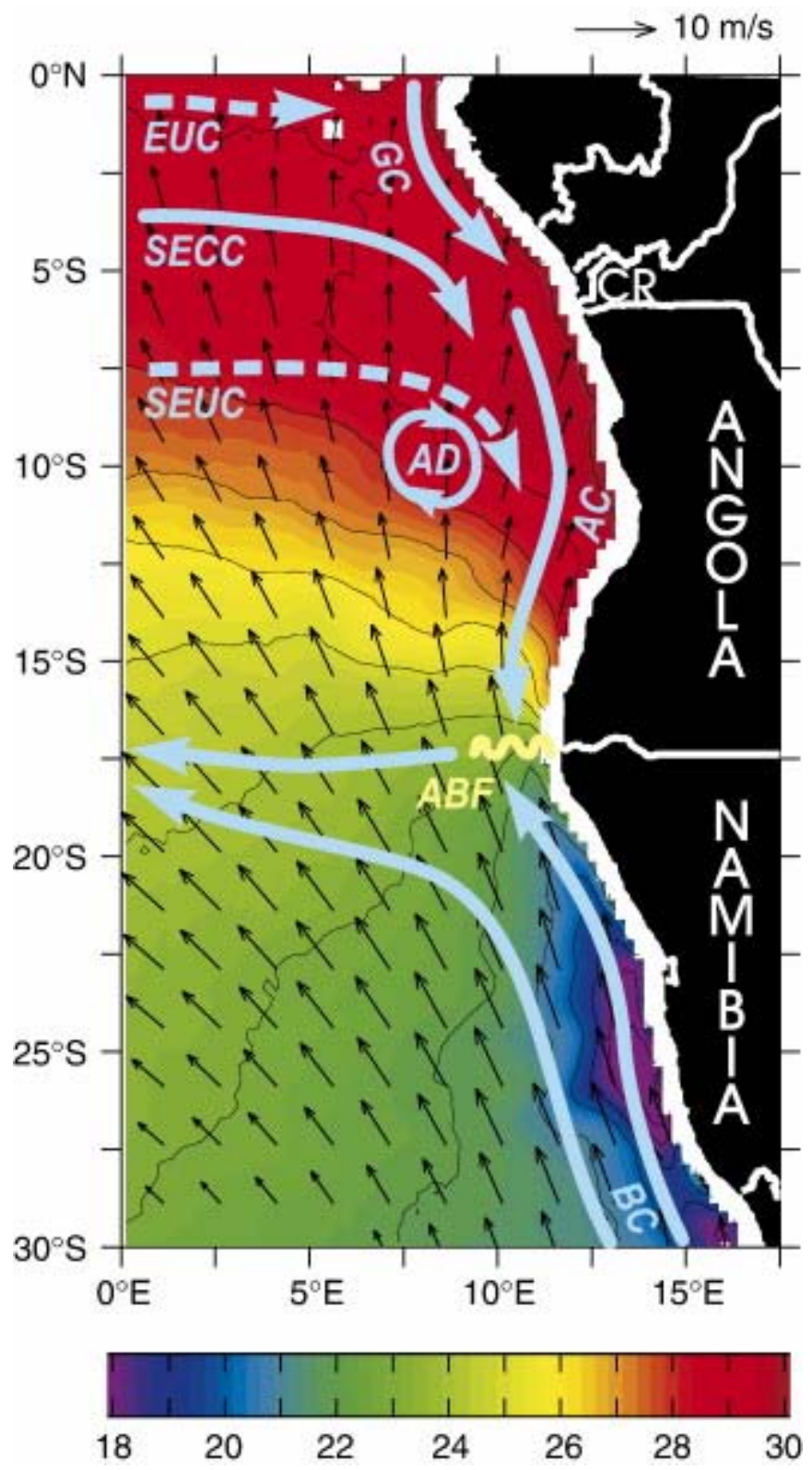

Fig. 1. Schematic of the major oceanographic features in the South East Tropical Atlantic in late austral summer with mean 1988-2006 March TRMM TMI SST and 1999-2006 QuikSCAT wind speed and direction. Major features are Equatorial Under Current (EUC), South Equatorial Counter Current (SECC), South Equatorial Under Current (SEUC), Gabon Current (GC), Congo River (CR), Angola Current (AC), Angola Benguela front (ABF) and Benguela Current (BC). SST is plotted every degree from 18 to $30^{\circ} \mathrm{C}$. Maximum wind speed is $8 \mathrm{~m} / \mathrm{s}$ in the south and minimum wind speed is $3 \mathrm{~m} / \mathrm{s}$ just north of the ABF. 

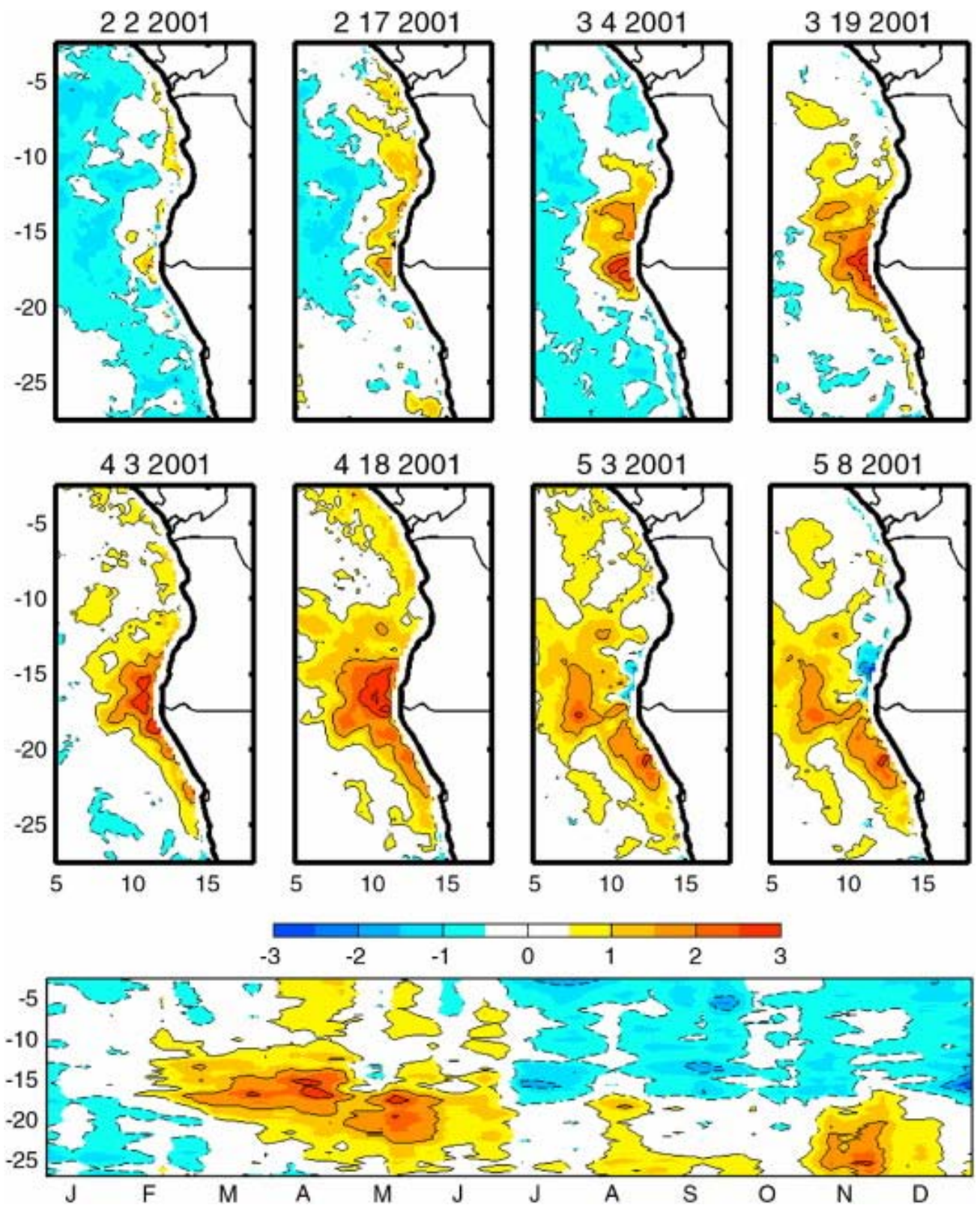

Fig. 2. Top: maps of weekly mean TRMM TMI SST anomaly from a 1998-2006 monthly running mean showing poleward propagation of above normal warm water from Angola to Namibia from February 2001 to April 2001. From left to right and top to bottom, the data are displayed every two weeks. Dates displayed correspond to the middle of the week. Bottom: time-latitude Hovmöller diagram of the weekly mean TRMM TMI SST anomaly in 2001. SST is averaged from the coast to $2^{\circ}$ longitude offshore. Contour Interval is $1^{\circ} \mathrm{C}$. 

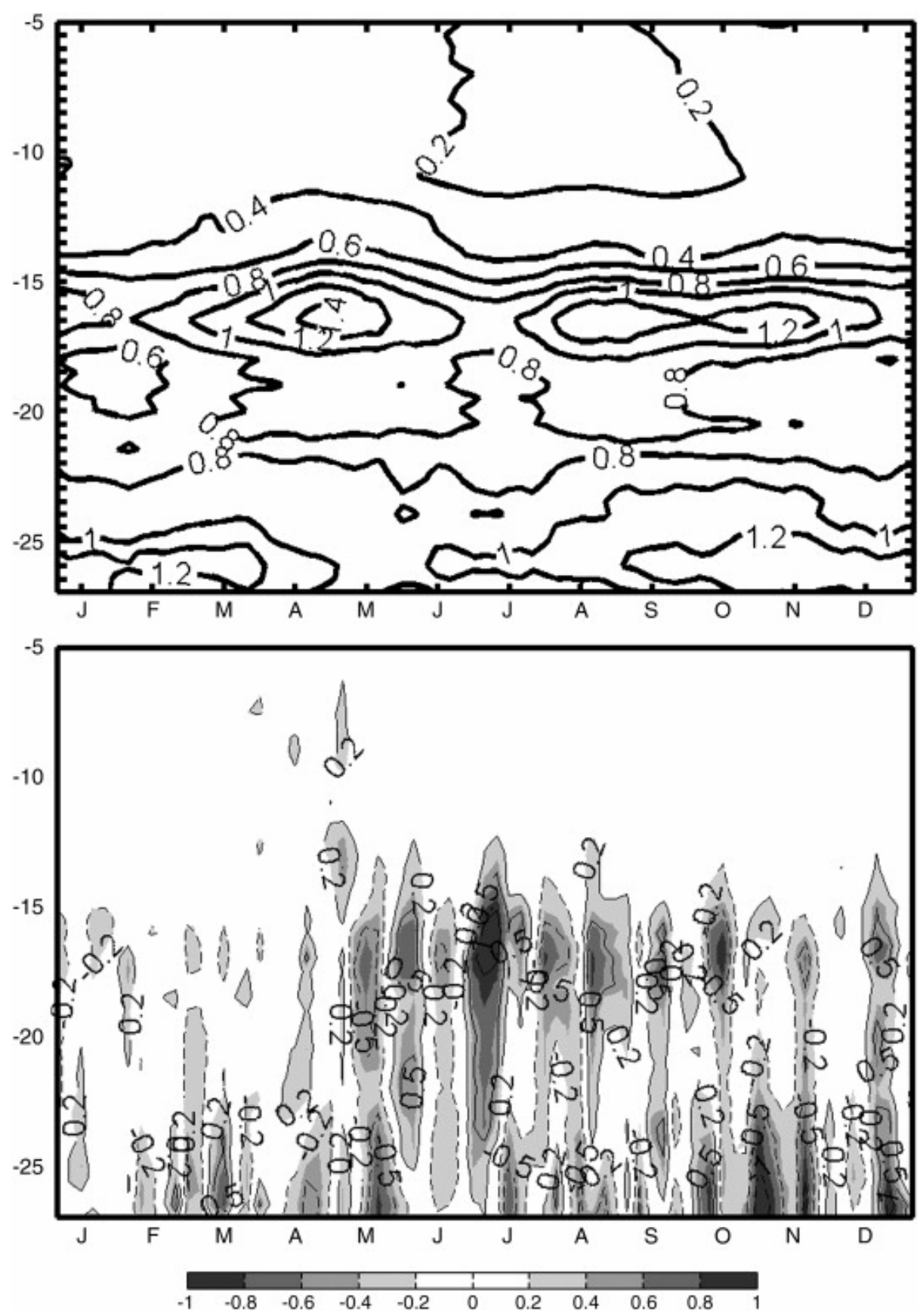

Fig. 3. Top: time-latitude Hovmöller diagram of the weekly mean 1999-2006 QuikSCAT meridional wind stress climatology along the coast from 5 to $30^{\circ} \mathrm{S}$. Bottom: weekly mean QuikSCAT meridional wind stress anomaly from a 1999-2006 monthly running mean in 2001 along the coast. Positive (negative) anomalies are in solid (dashed) lines. Data are averaged from the coast to $2^{\circ}$ longitude offshore. Unit is $\mathrm{dyn} / \mathrm{cm}^{2} \times 10$. 

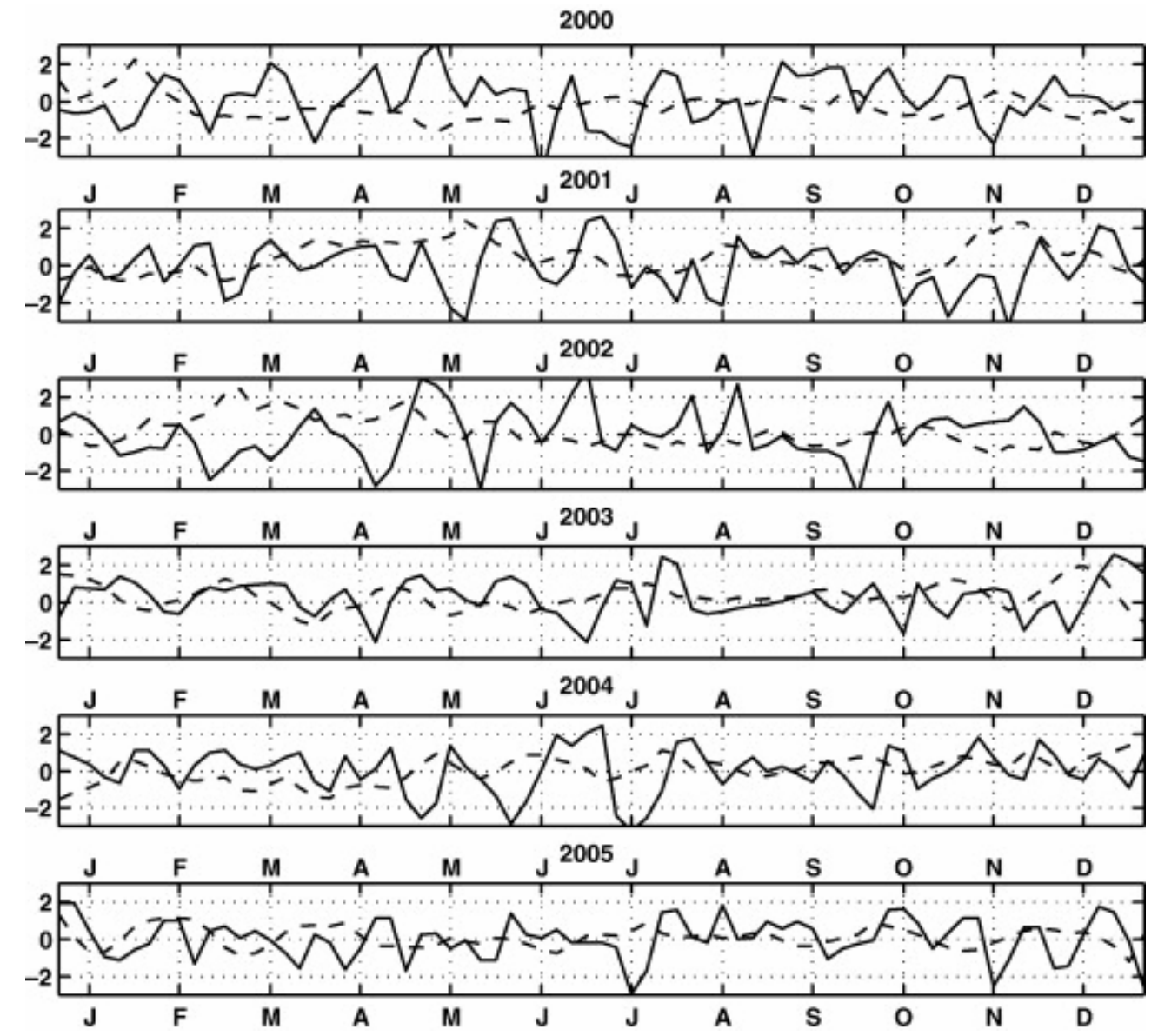

Fig. 4. Weekly TMI SST (dashed) and QuikSCAT meridional wind stress (solid) anomalies from a monthly running mean from 2000 to 2005 (top to bottom) averaged from $20^{\circ} \mathrm{S}$ to $25^{\circ} \mathrm{S}$ and from the coast to $2^{\circ}$ longitude offshore. QuikSCAT data is shown with a week lag. Unit is dyn/cm ${ }^{2} \times 10$. 

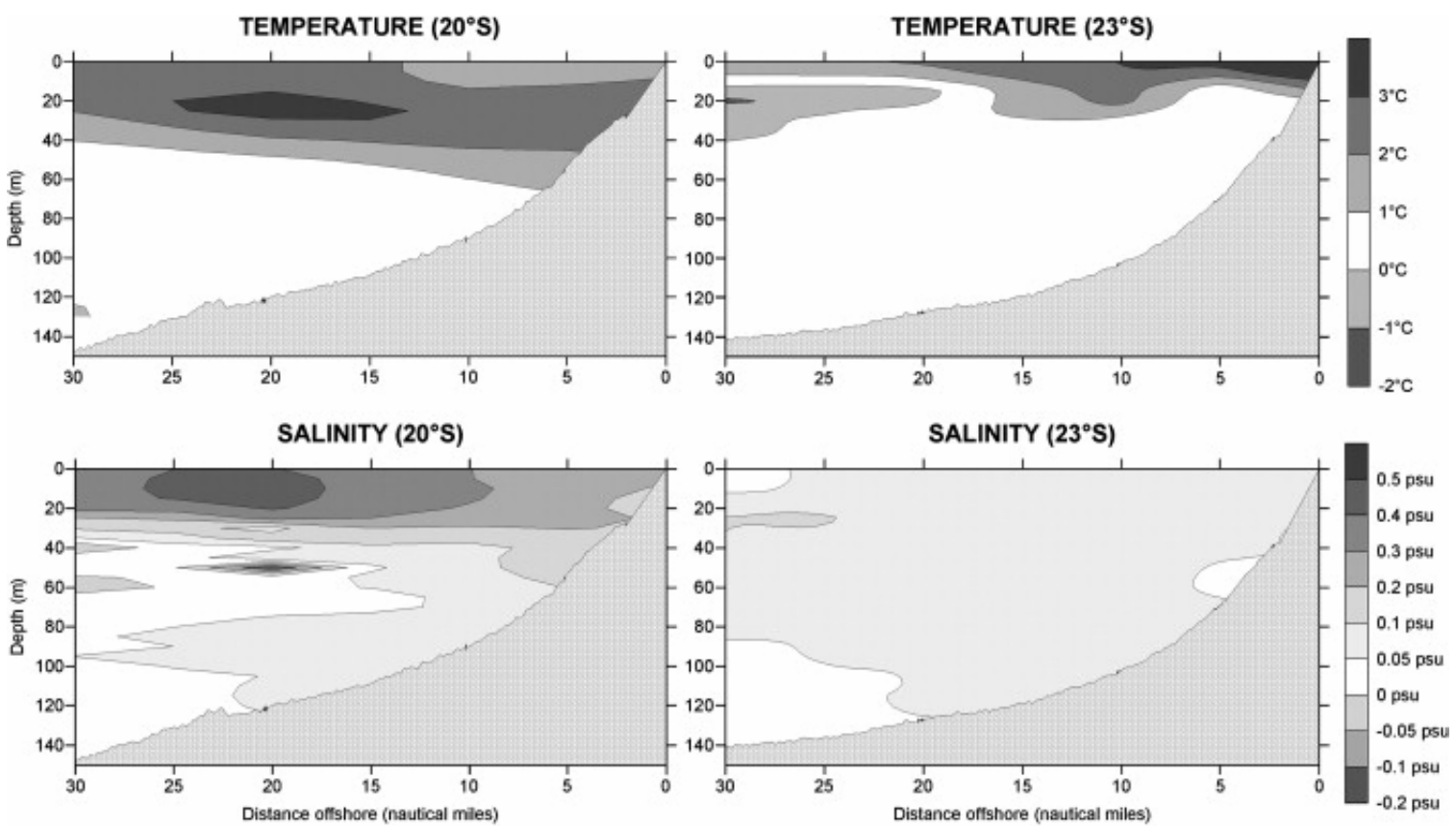

Fig. 5. Temperature (left) and salinity (right) anomalies observed during the end of March 2001 at $20^{\circ} \mathrm{S}$ (top) and $23^{\circ} \mathrm{S}$ (bottom) from the monitoring transect off northern and central Namibian coast respectively, from 0 to $150 \mathrm{~m}$ and from the coast to 30 nautical miles. Units are ${ }^{\circ} \mathrm{C}$ and psu respectively. Contour Intervals are $1^{\circ} \mathrm{C}$ and 0.1 psu respectively. Anomalies are estimated with respect to 1995-2006 mean. Positive (negative) anomalies are in solid (dashed) lines. 
$10^{\circ} \mathrm{S}-20^{\circ} \mathrm{S} / 8^{\circ} \mathrm{E}-14^{\circ} \mathrm{E}$
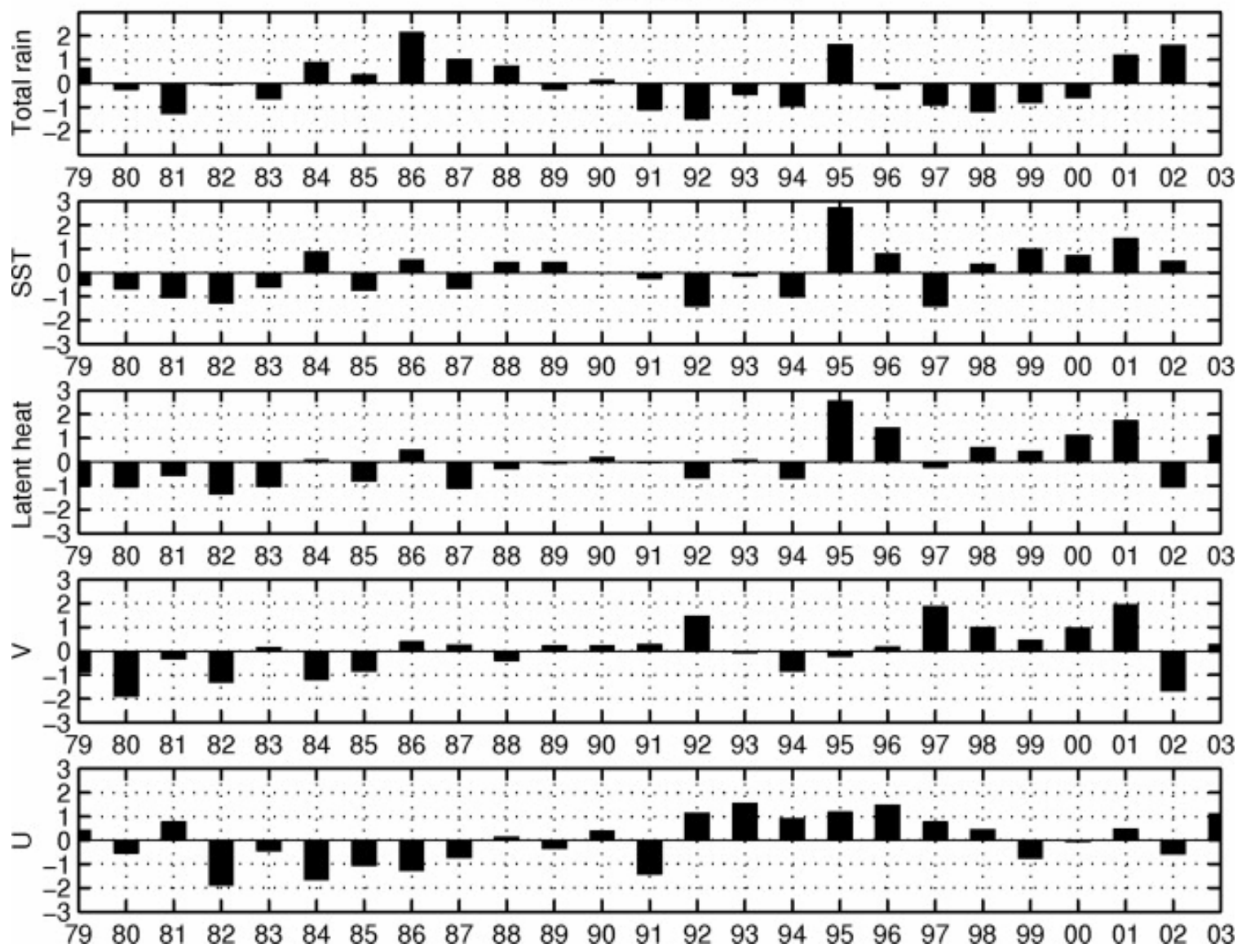

Fig. 6. From top to bottom: Late summer normalized anomaly (anomaly of the mean of February March and April of each year relative to the 1979-2003 mean of FMA divided by the standard deviation of 1979-2003 FMA) of GPCP-V2 total rainfall, Hadley SST, NCEP latent heat flux, NCEP meridional $(V)$ and zonal $(U)$ surface wind speed, averaged between $8^{\circ} \mathrm{E}$ to the coast and between $20^{\circ} \mathrm{S}$ to $10^{\circ} \mathrm{S}$. 

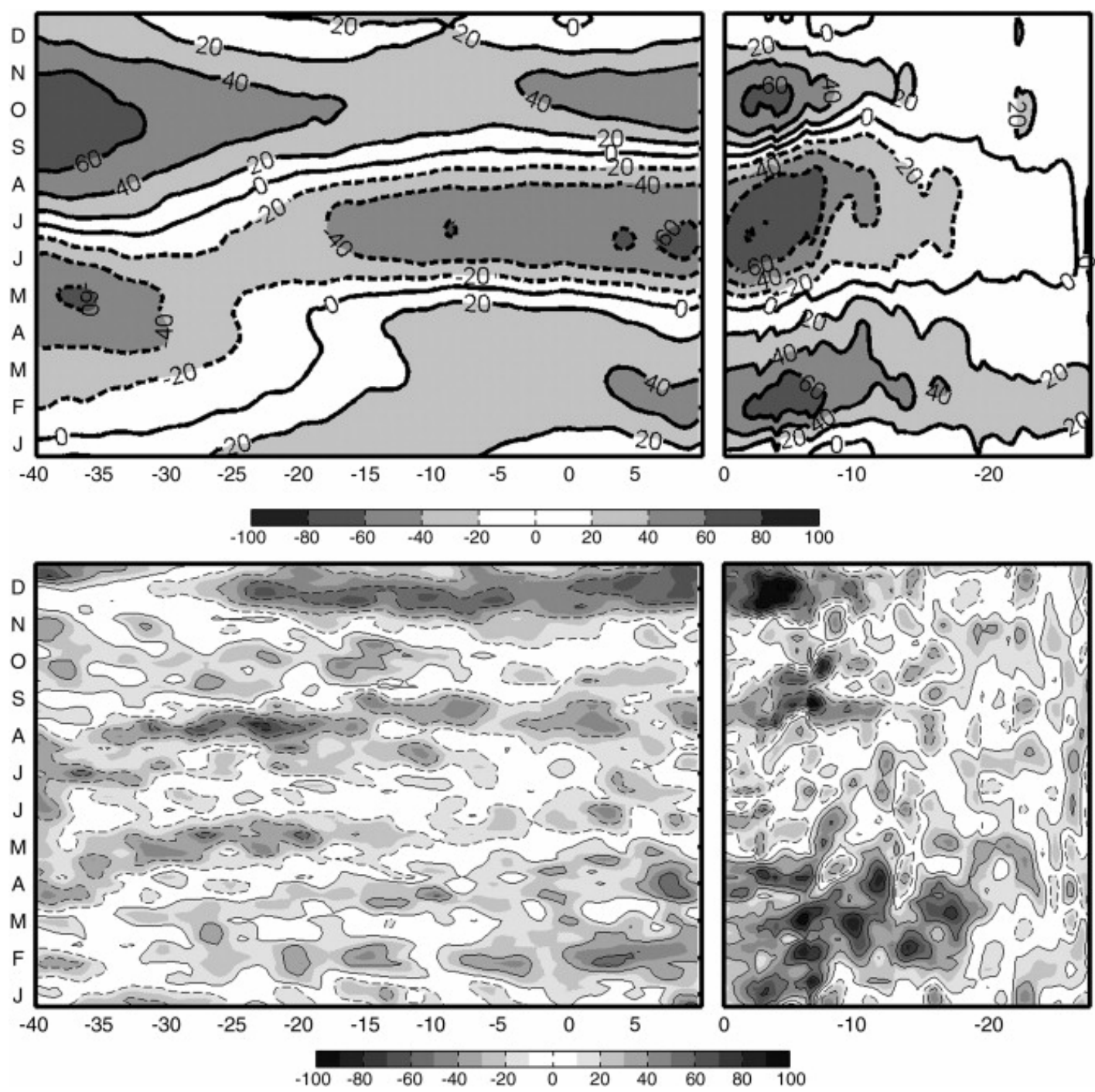

Fig. 7. Top: Climatology of longitude-time Hovmöller diagram of the weekly observed SSH along the equator (left) followed with latitude-time Hovmöller diagram of the weekly observed SSH along the coast from $0^{\circ}$ to $30^{\circ} \mathrm{S}$ (right) averaged from 1993 to 2006 . Bottom: Idem but for the weekly anomaly from a 1993-2006 monthly running mean in 2001. Units are in cm. Positive (negative) values are in solid (dashed) lines. 

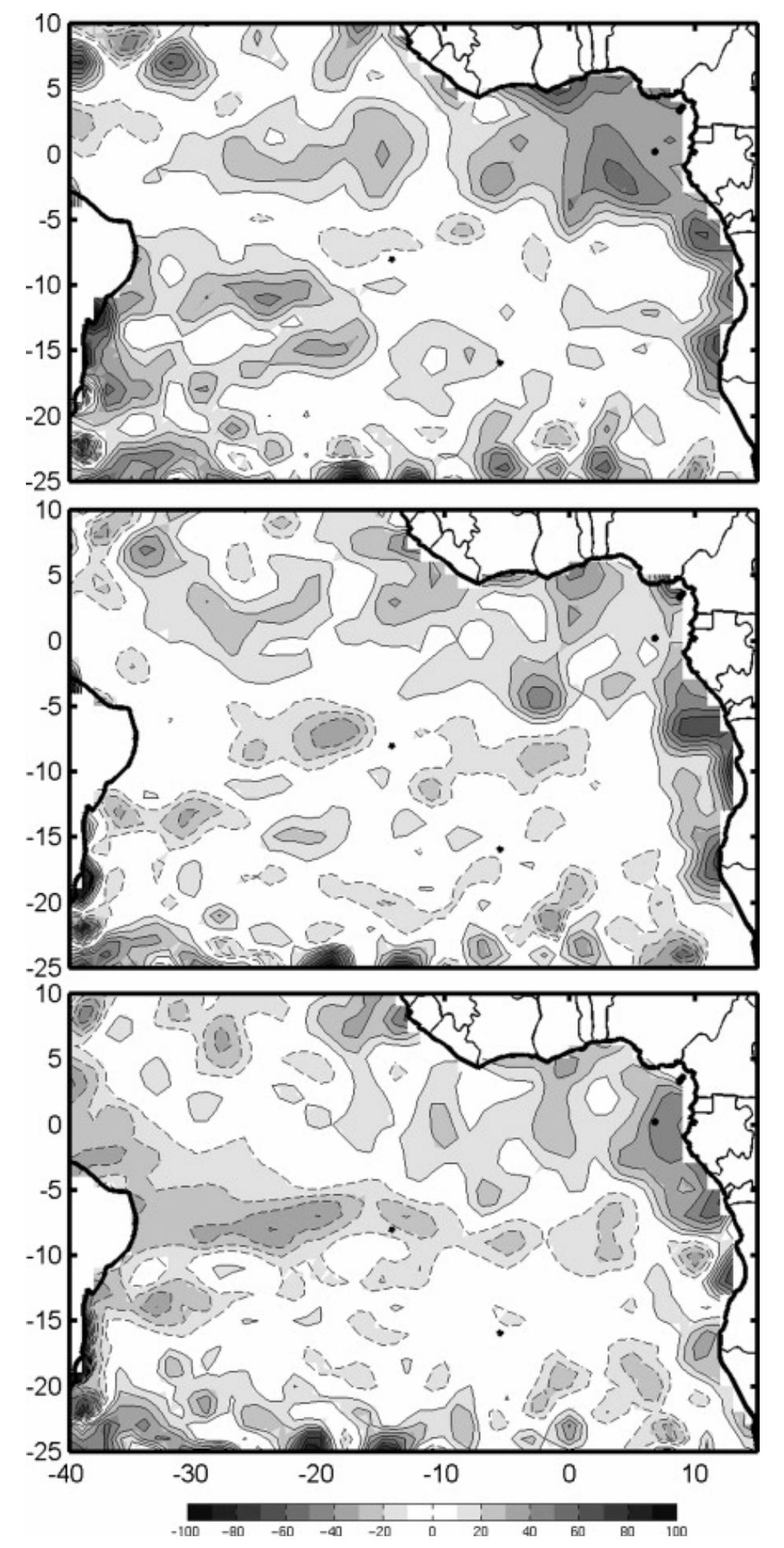

Fig. 8. Monthly anomaly of SSH from a 1993-2006 monthly mean for February (top), March (middle) and April 2001 showing an exaggeration of the seasonal cycle that year. Units are in $\mathrm{cm}$. Positive (negative) anomalies are in solid (dashed) lines. 

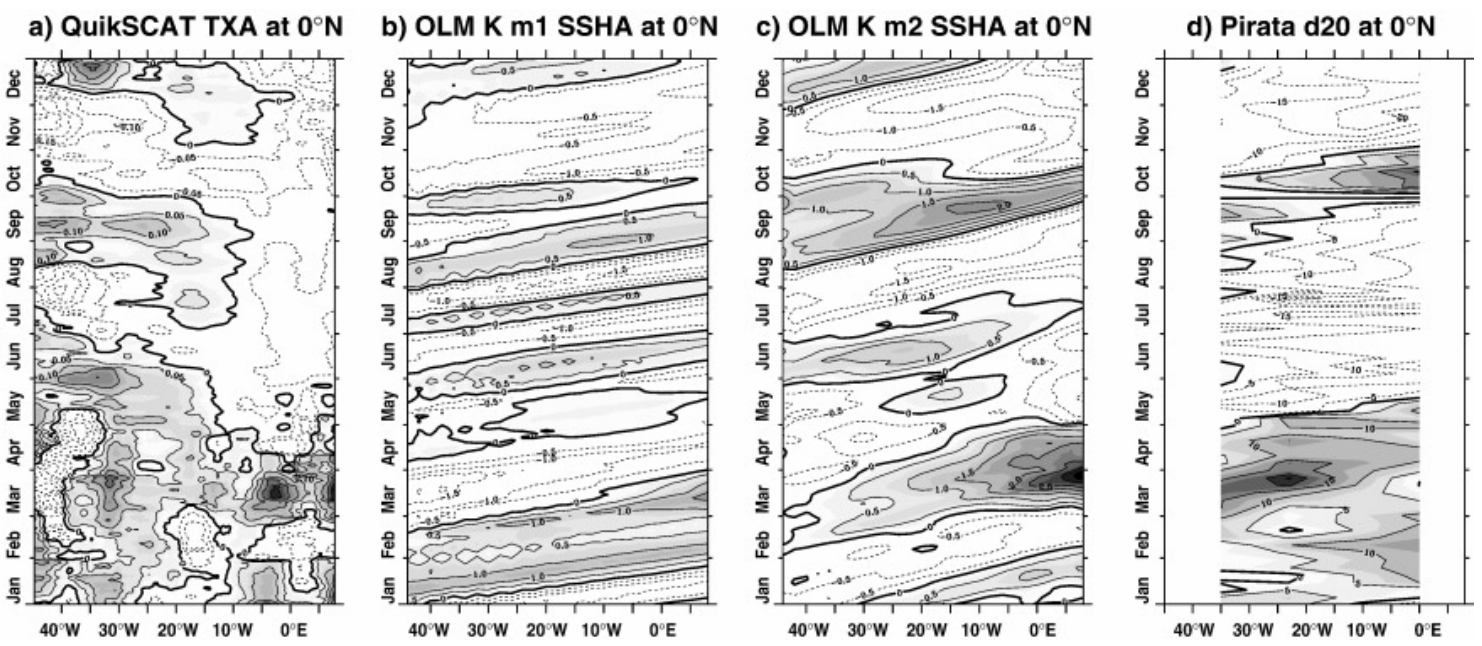

Fig. 9. From left to right: a) longitude-time Hovmöller diagrams along the equator of weekly QuikSCAT zonal wind stress anomalies (TXA) from a 1999-2006 monthly running mean in dyn $/ \mathrm{cm}^{2}$; b) the Ocean Linear Model first baroclinic mode Kelvin contribution to SSH anomaly in $\mathrm{cm}$; c) the OLM second baroclinic mode $\mathrm{K}$ contribution to $\mathrm{SSH}$ anomaly in $\mathrm{cm}$; d) longitude-time Hovmöller diagrams of the depth of the $20^{\circ} \mathrm{C}$ isotherm (d20) inferred from the PIRATA array of mooring along the equator showing propagation of $20^{\circ} \mathrm{C}$ isotherm anomaly and associated deepening of the thermocline from February to April 2001. Positive (negative) values are in solid (dashed) lines. 